\title{
Generation, characterization, and environmental implications of solid waste and its management in the Everest region
}

\author{
Sambuddha Bajracharya ${ }^{1}$, Anish Ghimire ${ }^{1, *}$, Mohan B. Dangi ${ }^{2}$ \\ ${ }^{1}$ Department of Environment Science and Engineering, Kathmandu University, Dhulikhel, Nepal \\ ${ }^{2}$ Department of Geography and City \& Regional Planning, California State University, Fresno, USA
}

(Received: 30 May 2021; Revised: 07 July 2021; Accepted: 03 August 2021)

\begin{abstract}
Managing solid waste is becoming a rather challenging task in remote areas, including the Mt. Everest region in Nepal, due to its cold climate, complex topography, and extreme environmental factors. Using published and unpublished literature and personal communications to key informants, this paper analyzes the situation of solid waste management in the Everest region as it relates to increasing tourism and possible environmental implications in the region. The study revealed that combined efforts from people of all levels associated with the mountain region would create a circular waste management system. The paper also reports the existing practices and planned activities for the essential process such as source segregation of waste, collection, use of material recovery facility, and recycling which could lead to sustainable solid waste management in the Everest region and beyond with similar context.
\end{abstract}

Keywords: Adverse environmental impacts, Everest tourism, Sagarmatha Nepal, solid waste challenges in mountain communities, Solid Waste Management in the Everest

\begin{abstract}
Introduction
Mountainous regions in developing countries experience significant challenges in handling the increasing quantity of solid waste. Under the pressure of expanding tourism activities and lack of proper waste management facilities, the pollution of land and water bodies in the proximity of human settlements in Nepal is an emerging threat. Environmental degradation due to open waste dumping and poor collection schemes in many hilly regions is associated with tourism activities and the regions' waste management practices. Additionally, given the geographical layout of many mountain communities, it is far more difficult to plan a waste management activity without altering the fragile ecosystem in the rugged environment. Furthermore, improper solid waste management (SWM) leads to health problems, drinking water contamination, and soil quality degradation.
\end{abstract}

The eight out of the fourteen highest peaks in the world and the many other prominent mountains in Nepal are the main source of attraction for tourists, trekkers, backpackers, and mountain climbers. Mt. Everest, with $8848.86 \mathrm{~m}$ height being the tallest mountain globally, draws global attention every year during the climbing season in April and May for many mountaineers aiming to summit it. Likewise, trekkers flock to the Everest Base Camp during the pre-monsoon in February through May and post-monsoon in September through December (Nepal, 2016). Despite having no direct access to the road, its remoteness, and harsh climatic conditions that prevail in the Himalaya, the flow of both domestic and international visitors is rather increasing. This has not only become the primary source of income for the local population, but it is also a key factor for development in the area. As tourism is the main livelihood strategy for the people of the Everest region, travel and trade-related business enterprises such as lodges, shops, restaurants, tea shops, and bakeries are established in almost every settlement (Posch et al., 2015). As of 2018, the travel and tourism industry contributed $7.9 \%$ to Nepal's GDP. However, contrary to the economic growth from tourism in the Everest region, there arise challenges of waste handling as a large volume of solid waste is generated along the trekking routes throughout the year. The problem is so pervasive that the Everest Base Camp trek was once labeled as a "garbage trail" and named the "world's highest junkyard" (Posch et al., 2015). However, with the collective efforts of different stakeholders, the SWM situation is improving in the region (Byers et al., 2019).

In the pre-COVID scenario, an initiative called Carry Me Back, where the visitors voluntarily carry back a $\mathrm{kg}$ of preprocessed waste from Namche Bazar to Lukla (2 days trek), has been successful in bringing more than $2,000 \mathrm{~kg}$ of waste

*Corresponding author: anishghimire@gmail.com; anishghimire@ku.edu.np 
Nep J Environ Sci (2021), 9(2), 1-11

https://doi.org/10.3126/njes.v9i2.37381

from Namche to Lukla. The waste collected was previously burned, but some waste is now transported to Kathmandu for upcycling (Pant, 2021). Considering the increasing number of landfills in the region and the establishment of an environmental station, a collection point where multiple bins are placed for different types of waste, which is fenced and roofed, is placed at Sagarmatha Next Interpretation Center in Syangboche, aiming to promote source segregation and replace landfills (Byers et al., 2019)(Sagarmatha is a Nepali word for Everest and Syangboche is one of the settlements in the area). With the recent initiatives, the solid waste scenario in Sagarmatha National Park and Buffer Zone (SNPBZ) is likely to be improving.

The piling of garbage and solid waste has direct and indirect impacts on the fragile mountain environment resulting in ecological degradation due to already limited waste management infrastructures. Usually, in inaccessible high areas and protected ranges in the Himalayas, sustainable management of natural resources is at greater risk from increasing human activities. This is particularly true in Nepal because people and parks coexist in Nepal, unlike other parts of the globe where human settlement is discouraged in the national parks. In such a scenario, the inefficient SWM programs can bring ecological disturbance such as surface water contamination, soil pollution, and other sanitary problems leading to disease/infections (Manfredi et al., 2010; Pillai et al., 2014), and may lead to a decline in tourism and have a long-term economic impact on the area.

A decade has passed since the waste generation situation in the Everest region is well reported in scientific studies (Manfredi et al., 2010; Zuser et al., 2011). The studies revealed that plastics, metals, and paper are major problems of the region (Manfredi et al., 2010; Zuser et al., 2011). A detailed study on solid waste issues and prospective solutions about the locality was reported in 2019, including information regarding active landfills, regular SWM practices, and precovid initiatives to handle solid waste (Maharjan \& Gustafsson, 2019). Upon overviewing the waste situation, it appears that a solid waste management plan was developed for SNPBZ (Byers et al., 2020). This paper aims to assess the current situation of SWM in the Everest region, its contemporary SWM practices, recent initiatives, and future plans and their implementation challenges in light of the current COVID-19 pandemic - thereby cultivating further ideas for future waste management prospects.

\section{Materials and methods}

\section{Study area}

Everest region, also known as the Khumbu region, lies in the eastern Himalayas of Nepal, which is one of the most visited trekking destinations in Nepal (Fig. 1). Sherpa people, who are primary inhabitants of the region, are also renowned for their skills in mountaineering. Khumbu region includes villages like Thame, Khumjung, Pangboche, Pheriche, Khunde, and the wealthiest village in Nepal, Namche Bazaar. Sagarmatha National Park, a United Nations Educational, Scientific and Cultural Organization (UNESCO) World Heritage Site, located in the region consists of glaciers, deep valleys, and majestic peaks, including Mt. Everest (UNESCO, 2007).

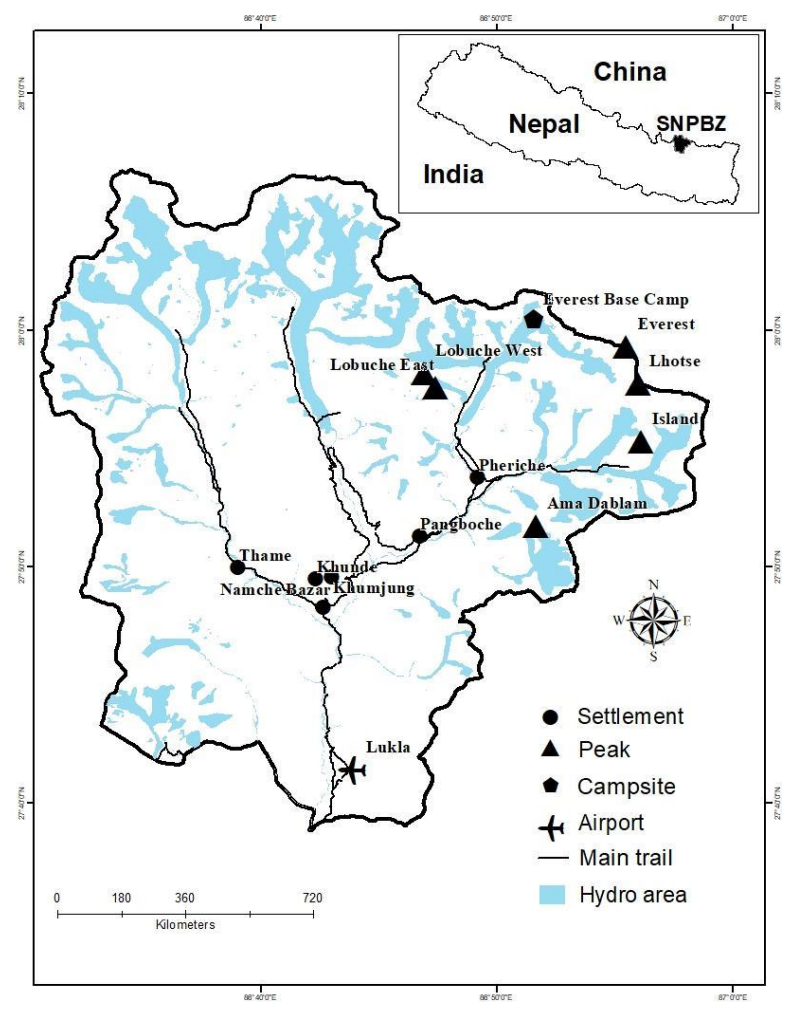

Figure 1 Sagarmatha National Park and Buffer Zone (SNPBZ) (ICIMOD, 2011).

The main trekking path in the region starts from Lukla (Fig. 1), and apart from the main settlements, such as Namche Bazar, Khumjung, Khunde, Pheriche, and Pangboche along several large and small settlements can be found in the route. The SNPBZ is visited every year by more than 60,000 trekkers and mountaineers from around the world. The number of lodges is increasing along the trekking routes. In 2010, the number of lodges in Namche Bazar was around 30, and it has gone up to more than 60 lodges recently (Byers et al., 2020). The increasing number of tourists every year is probably because of the change in the region's economic, environmental, and sociocultural conditions (Nepal, 2005).

\section{Data collection and analysis}

This study was conducted through a literature survey, using published and unpublished information on SWM in the Everest region. At first, the solid waste context of the area was thoroughly researched, and the ecological disturbance from the solid waste activities reported was considered. Upon examining past solid waste practices and their approach, 
Nep J Environ Sci (2021), 9(2), 1-11

https://doi.org/10.3126/njes.v9i2.37381

additional issues encountered by existing SWM operations were assessed. Further to get an insight on the effect of COVID-19 on SWM in SNPBZ, personal communication was conducted with the program development officer of Sagarmatha Pollution Control Committee (SPCC), project director of Sagarmatha Next, and chief executive officer of Blue Waste to Value. The discussion and conclusions of this paper are based on the literature survey and the personal communications with the relevant stakeholders involved in the SWM in the region.

\section{Results and discussion}

\section{Solid waste management in the Everest region}

The current waste management system in SNPBZ is based upon the displacement of waste from one place to another (Byers et al., 2019). The stakeholders dedicated to waste management are trying to develop environment-friendly, costeffective, and feasible solutions. The conventional approach to SWM, such as improperly designed waste pits and open burning practices, seems to be contaminating the water sources and air, posing a serious threat to human health and the environment (World Bank, 2021). The volume of the waste pits being smaller than the volume of the waste generated might have left the waste handlers no choice other than to burn the waste.

The private sectors (lodges, trekking companies, and contractors), the public sector (SNPBZ, Nepal Mountaineering Association (NMA), rural municipalities, district administration, and police), and community-based organizations like Sagarmatha Pollution Control Committee (SPCC), buffer zone committees, and village pollution control committees) are responsible for governing solid waste management in the Everest region. Among them, SPCC seems to be the most active as it is a community-based organization established and run by the local community of Khumbu. The SPCC and other local community initiatives are responsible for collecting, separating, and treating solid waste in the region. Under the new federal system, Khumbu Pasang Lhamu Rural Municipality (KPLRM) now has ultimate responsibility for waste management in the Khumbu region. Therefore, SPCC is actively seeking ways to collaborate with the KPLRM to best achieve mutually beneficial goals. From monitoring illegal climbers to door-to-door garbage collection services in Namche Bazaar and Lukla (with minimum service charge), collaborating with various government and nongovernment bodies, private sectors, and tourism stakeholders, SPCC has been managing the environment around the Everest region with due consideration of sanitation and hygiene. SPCC is collaborating with Sagarmatha Next, a non-profit organization and Blue Waste to Value, a Kathmandu Based social enterprise, which is moving towards an innovative SWM approach. This includes possible upcycling and recycling of waste materials, turning trash into treasure by using waste for artistic purposes.

The SPCC, a Sherpa-run nonprofit organization, established in 1991, is supported by the World Wildlife Fund - Nepal and the Ministry of Culture, Tourism and Civil Aviation. It is registered legally under the District Administration Office in Solukhumbu, where Mt. Everest is located and is also listed with the Social Welfare Council (SPCC, 2020). Its head office is in Namche Bazaar, and several branch offices are situated at different settlements and base camps. It currently has 20 permanent and 50 seasonal staff to carry out different SWM activities (SPCC, 2020). It implements waste management strategies at several places around the Everest Base Camp and manages activities including building waste management infrastructures, waste segregation, waste disposal, etc. The SPCC has arranged 106 permanent dustbins since 2013 with the help of many sponsors, which has minimized littering drastically. The SPCC initiated recycling tents to make handbags and organize cleanup campaigns and several awareness programs to educate local communities, trekkers, guides, porters, and students.

As of 2018, within the Everest region, SPCC has built nine organic/non-combustible waste collection centers in major settlement areas, two waste disposal facilities in Namche Bazaar and Lukla, and five incinerators near major communities. Likewise, the construction of 14 toilets had been completed along the trekking trail and in several base camps, including the base camps of Mt. Ama Dablam, Island Peak, and Lobuche Peak. Currently, SPCC is providing door-todoor waste collection services to 109 lodges, restaurants, cafes, and shops in Namche Bazaar and 65 households and various business enterprises in Lukla (SPCC, 2018). The establishment of an environmental station, a collection point where multiple bins are placed for different types of waste (plastics, paper, glass, and organic waste), which is fenced and roofed, is placed in Sagarmatha Next Interpretation Center, Syangboche aiming to promote source segregation and replace landfills (Byers et al., 2019). Those who do not want the services provided by SPCC, such as door-to-door collection, can place their waste in the environmental station. Moreover, Sagarmatha Next has built one test environmental station adjacent to the Sagarmatha Next facility at Syangboche as a showcase. The further plan to build environmental stations to replace open pits has been delayed since March 2020 due to the COVID-19 situation. A small material recovery facility (MRF) has been established near Pheriche by the SPCC, which has a concrete floor to prevent seepage and a fence that restricts the animals. This attempt has enabled the segregation of some valuable recyclables, including aluminum cans and glass bottles. 
Nep J Environ Sci (2021), 9(2), 1-11

https://doi.org/10.3126/njes.v9i2.37381

The SPCC classifies solid waste in the region into two categories: burnable and non-burnable. Burnable waste includes paper, plastics, textiles, clothes, and plastic bottles whereas non-burnable waste include cans, tins, portable gas stove with cylinder (referred as EPI - Euro Pleasure International gas), oxygen cylinder, glass bottles, batteries, and medical supplies. Though SPCC categorizes paper, plastics, and plastic bottles into burnable waste, they may require further reconsideration because they can emit harmful pollutants into the air while burning. Various levels of treatments may be required for different types of waste, based on the properties and composition of the material. A total of $35,000 \mathrm{~kg}$ of non-burnable waste was transported from Khumbu to Kathmandu in 2017 and 2018 to reuse or recycle. Perhaps, even more recyclable waste can be transported to Kathmandu by strengthening the collaboration with airline companies that generally bring waste from Lukla to Kathmandu (Byers et al., 2019). As Everest Base Camp is above $5000 \mathrm{~m}$ altitude, organic waste will take time to decay since the biodegradation rates are greatly reduced in colder temperatures, and rubbish cannot be properly buried or treated.

A recent study reports that the number of active open dumping pits within the SNPBZ has increased from 58 to more than 75 in just two years, from 2017 to 2019 (Byers et al., 2020). A different approach is promptly needed to tackle this waste as the number of tourists visiting the region increases every year. The record of tourism statistics presented in Fig. 2 displays that from 2013 to 2018, the number of foreign tourists visiting the Everest region is increasing except for the decrease in 2016, immediately after the massive earthquake of 7.8 magnitudes that hit Nepal in April 2015. Although the earthquake heavily affected the incoming tourists for a year, the tourism industry bounced back in 2017 with a growing number of visitors than ever before. In 2017 the number of tourists visiting the region was 45,112, which went up to 56,303 in just a year. Similarly, Table 1 shows the number of foreigners visiting the Everest region by month (Nepal Tourism Statistics, 2018). Lately, the number of visitors coming into the area has been impacted by COVID19 and subsequent lockdowns, and this has directly affected the livelihood of people in SNPBZ. The mountaineering expeditions are slowly resuming, but the number of trekkers has not recovered due to the second wave of COVID-19 impacting Nepal since April of 2021 (Y. Sherpa, personal communication, June 24, 2021).

\section{Waste generation and characteristics in the Everest region \\ Fundamentally, the waste generated in the Everest region is goods that are imported from Kathmandu (Maharjan \& Gustafsson, 2019). The sources of waste are kitchen waste, medical waste, mountaineering and trekking equipment, and local markets and shops. The solid waste generated by trekkers is transported to dumping or collection sites designated by SPCC either by local workers or mules. After transporting to the collection site, the burnable waste, including paper and plastics, are burned while the non-burnable materials are separately stored in a pit near to SPCC station (Maharjan \& Gustafsson, 2019; Byers et al., 2019).}

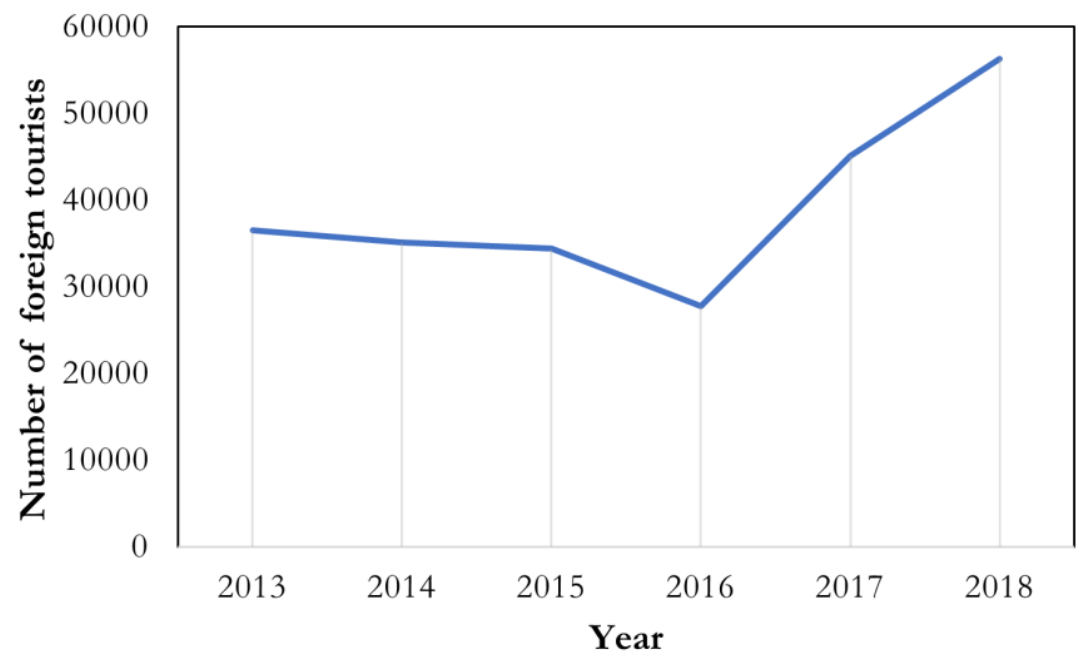

Figure 2 Approximate foreign tourist arrivals in SNPBZ (Nepal Tourism Statistics, 2018).

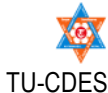


Table 1 The number of foreign tourists visited the Everest region 2018-2019 (Nepal Tourism Statistics, 2018).

\begin{tabular}{ll}
\hline Months & Visitors \\
\hline April-May & $\mathbf{1 0 , 5 2 6}$ \\
May-June & 2,692 \\
June-July & 352 \\
July-August & 315 \\
August-September & 1,597 \\
September-October & $\mathbf{9 , 3 9 5}$ \\
October-November & $\mathbf{1 1 , 3 5 2}$ \\
November-December & 3,673 \\
December-January & 2,271 \\
January-February & 1,192 \\
February-March & 3,244 \\
March-April & $\mathbf{9 , 6 9 4}$ \\
Total & $\mathbf{5 6 , 3 0 3}$ \\
\hline
\end{tabular}

The number of incinerators running in the areas went up to five in 2018 from a single facility located in Lukla with about $30 \mathrm{~kg} / \mathrm{h}$ of theoretical capacity (Manfredi et al., 2010; SPCC, 2018). Similarly, open dumping pits consisting of nonsegregated and non-degradable wastes, which are occasionally set on fire, were prevalent (Manfredi et al., 2010). Even though a decade has passed, the waste is still burned in open pits and incinerators (T. Gustafsson, personal communication, June 22, 2021). The overview of categories of waste classified by SPCC generated from various mountains and peaks is presented in Table 2.

Table 2 The garbage generated by expedition groups at Everest, Lhotse, Nuptse, Amadablam, and other mountains (FY 2016/2017 and 2017/2018) (SPCC, 2018).

\begin{tabular}{lcc}
\hline Waste components & \multicolumn{1}{c}{ Amount of waste generated } \\
\cline { 2 - 3 } & FY- 2016/2017 & FY- 2017/2018 \\
\hline Burnable garbage & $17703 \mathrm{~kg}$ & $25599 \mathrm{~kg}$ \\
Human waste & $4716 \mathrm{~kg}$ & $12995 \mathrm{~kg}$ \\
Kitchen waste & $3595 \mathrm{~kg}$ & $4010 \mathrm{~kg}$ \\
EPI gas (stoves) & $1728 \mathrm{pcs}$ & $1735 \mathrm{pcs}$ \\
Batteries & $1513 \mathrm{pcs}$ & $2179 \mathrm{pcs}$ \\
Tin & $1263 \mathrm{~kg}$ & $2537 \mathrm{~kg}$ \\
Glass bottle & $668 \mathrm{~kg}$ & $763 \mathrm{~kg}$ \\
\hline
\end{tabular}

Manfredi et al. (2010) calculated the per capita waste generation to be around $123 \mathrm{~g} / \mathrm{d}$ and found the waste generated during the peak tourist seasons in April through May and October through November to be 4.6 tonnes per day. Considering this data and assuming that the average tourist stays 12 days and with total visitors per year of 60,000 , more than 88.5 tonnes of solid waste is produced by visitors in the Everest area in a single year. However, the per capita waste generation has likely increased in ten years since 2010, given the growth in economic activities in the region. Likewise, according to Zuser et al. (2011), the average amount of solid waste generated in a hotel or lodge by a trekker was calculated to be $213 \mathrm{~g} / \mathrm{d}$, higher than the national average per capita waste generation of $170 \mathrm{~g} / \mathrm{d}$ (ADB, 2013). The increase in visitors and the number of lodges seem to have contributed to the larger volume of waste and thus the growing number of waste pits (Byers et al., 2020).

Figure 3 shows the composition of solid waste in the Everest region conducted by Manfredi et al. (2010) and Zuser et al. (2011). The average composition of waste generated by tourists consists mainly of residues (kitchen waste and dust), plastics, brushes, and toilet paper. The residual waste seems to have decreased along with glass and metals, but the usage of 
Nep J Environ Sci (2021), 9(2), 1-11

https://doi.org/10.3126/njes.v9i2.37381

plastics is increasing annually, probably because of the rising number of tourists in SNPBZ. Plastics and polyethylene terephthalate (PET) bottles constitute $21.4 \%$ of collected waste and are the most problematic type of waste in the region as they accumulate in large quantities over time (Zuser et al., 2011). As the plastic materials are burned, they release toxic chemicals like polychlorinated dibenzodioxins (PCDD) and polychlorinated dibenzofurans (PCDF) in considerable quantity, which directly affects human health and pollutes the surrounding soil and air (Manfredi et al., 2010; Zuser et al., 2011).

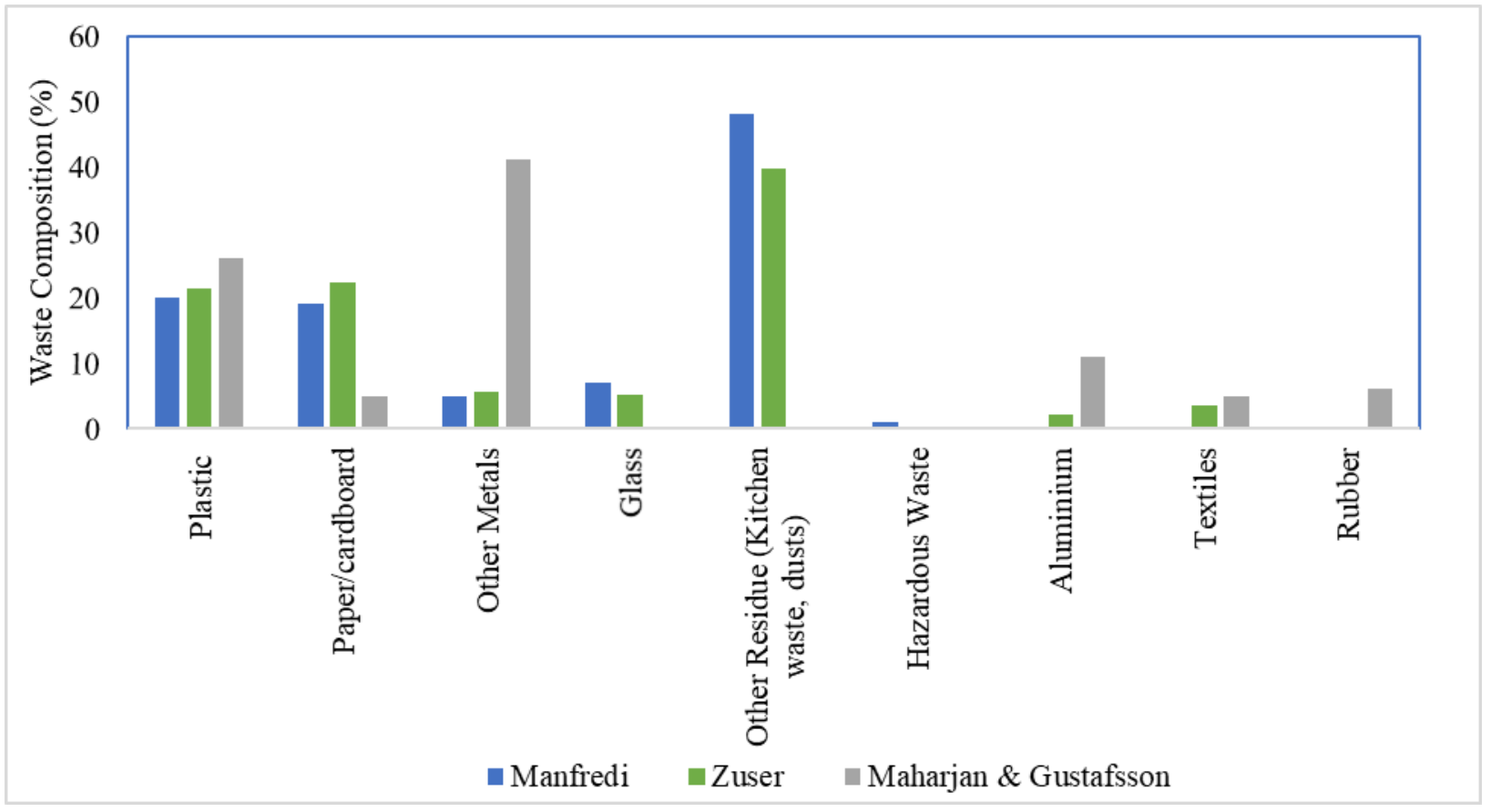

Figure. 3. Solid waste composition in the SNPBZ (Manfredi et al., 2010, Zuser et al., 2011; Maharjan \& Gustafsson, 2019).

A study published in 2010 by Kathmandu University had reported the waste generated per capita in SNPBZ to be $0.43 \mathrm{~kg} / \mathrm{d}$, and the waste composition revealed was $7 \%$ plastics, $2 \%$ metals, $9 \%$ paper, $79 \%$ kitchen waste, and $1 \%$ other (Khanal, 2009). The kitchen waste is used to feed the cattle or practice composting, and plastics, glass, and metals are the major concerns (Khanal, 2009). The practice of feeding the kitchen waste to cattle or composting is still ongoing as it has become a habit (Y. Sherpa, personal communication, June 24, 2021).

A recent report (Maharjan \& Gustafsson, 2019) has a comprehensive view of problems and solutions of solid waste management within the SNPBZ. The study revealed that the waste composition in the waste pits consisted of $26 \%$ plastics, $6 \%$ rubber, $11 \%$ aluminum, $5 \%$ paper, $41 \%$ heavy and light iron, and 5\% textile (Maharjan \& Gustafsson, 2019). This waste composition is different from the overall waste composition reported by the two former studies (Fig. 3). The waste composition in Maharjan and Gustafsson (2019) was assessed from the waste disposed at the waste pits, which may not have included the household organic wastes. This composition ratio shows the plastics and metals are still a major problem in the region. The success rate of upcycling and recycling by Blue Waste to Value might increase soon as they have started partnering with Mountain Waste Repurpose (MOWARE) design, a design-led intervention that gives new meaning to the waste. Also, after the COVID-19 situation, they are planning to collaborate with Netherland's Super Local team that's co-creating sustainable products with innovative design.

Besides contributing to solid waste volumes, the tourists leave more than just footprints on the base camps and climbing trails. The growing quantity of human feces in the area has further added challenges to the waste management situation and is imposing health risks to the climbers as the only source of drinking water is melted snow at higher altitudes. Climbers dig a hole in the snow to defecate, so the exact amount of human excrement is impossible to calculate, as it is seen only 
Nep J Environ Sci (2021), 9(2), 1-11

https://doi.org/10.3126/njes.v9i2.37381

when the snow melts. Nevertheless, NMA estimates the number to be more than 7.7 tonnes for a season of two months alone (Fox News, 2019). Presently there are no regulations on the handling of human waste in the region. Some climbers use biodegradable bags containing enzymes that decompose human waste (Fox News, 2019). It takes about three to six months to disintegrate human waste in the bags (Cordrey, 2009). Similarly, the feces disposed of in plastic bags is swept away by the river water threatening the health of downstream communities that rely on the surface water for drinking (Wills, 2019).

The management of human waste, i.e., excreta, has been an emerging problem in the locality. Recently, SPCC has partnered with Mt. Everest Biogas Project, an initiative launched in 2010 (EBP, 2019). This project aims to decrease the contamination of water bodies through the management of human waste using anaerobic digestion. The project plans to construct a biogas digester to be suited for extremely cold conditions at higher altitudes. The proposed biogas digester will consist of insulation beneath the foundation and in the cavities of walls and roof to retain the digester heat and will have heating facilities. A shelter over the digester will give a controlled situation to raise the surrounding air and ground temperature and warm-up or defrost water and waste items. Also, solar array panels are planned to be used to transmit heat into the digester. The outcome would be methane gas, which can be used for cooking or lighting, and effluent as fertilizers for crops. The project was designed to operate from the spring of 2019, but it is yet to be developed (EBP, 2019). Anaerobic digestion of human excreta alone is not good for biogas production, but it can be effectively mixed with household organic waste for enhanced methane production (Rajagopal et al., 2013; Afifah \& Priadi, 2017). Therefore, the human excreta may be combinedly digested with food waste generated by the climbers at the basecamps for higher energy recovery, which will make the project more viable.

\section{Implications of current and planned SWM activities}

While conducting environmental assessments of streams and rivers along major trekking routes in the Everest region, Manfredi et al. (2010) found total phosphorus (P) content in river samples ranging from 0.02 to $0.66 \mathrm{mg} / \mathrm{l}$. The numbers are seven and thirteen times higher than the numbers recommended by USEPA (2000) for streams and river water $(0.1 \mathrm{mg} / \mathrm{l})$ and streams entering the lakes $(0.05 \mathrm{mg} / \mathrm{l})$. In the four Gokyo lakes and Imja and Pyramid Inferior Lakes, the total $\mathrm{P}$ ranged from 0.01 to $0.42 \mathrm{mg} / \mathrm{l}$, thus exceeding the USEPA (2000) standard range of 0.01 to $0.03 \mathrm{mg} / 1$ for lake and reservoirs. The findings suggest the high possibility for algal blooms in the water bodies. The higher levels of nutrients in the water sources are the results of effluents from the nearby camps, lodges, and hotels (Manfredi et al., 2010).

Escherichia coli and Streptococcus faecalis bacteria were recorded in some water bodies in the SNPBZ (Ghimire et al., 2010). Improvement in toilets and septic tanks can prevent the movement of pollutants from sources to the water bodies. Community drinking water sources examined for E. coli and coliform bacteria showed that water samples from the lower altitude $(<3500 \mathrm{~m})$ contained more $E$. coli than water samples from higher $(>3500 \mathrm{~m})$ (Nicholson et al., 2018). The likely causes seem to be the greater density of livestock and areas devoted to agriculture and deforestation in the settlements in lower-elevation (Nicholson et al., 2017). This bolsters the argument that growing human activities and the flow of tourists in the area correlate with the change of $E$. coli contamination.

The waste collection pits are also situated in improper locations in parts of SNPBZ. For example, in Lukla and Namche Bazar, dumping pits are near water sources (Maharjan \& Gustafsson, 2019). Leaching of heavy metals from open dumping pits through rockslide material can have adverse impacts due to high porosity and permeability. The construction of disposal sites on hard surfaces in higher terraces can be done to prevent the infiltrations of landfill leachate and contamination of water sources to some degree. The construction of a small sanitary landfill and appropriate handling of waste with proper cover and maintenance could minimize the leachate flow and reduce the emission of greenhouse gases. The transportation of waste from the point of generation to the landfills is also a common problem in the Everest region, which is often done by using animals such as yaks, horses, and mules (Alfthan et al., 2016). This practice could lead to spillage of garbage and leakage of leachate along the way, thus contaminating a pristine environment in the region. By depositing solid waste in garbage bins according to its type along the trail, it will make the job easier for workers to collect the waste from the bins situated at the designated sites than the ones where a single bin is placed to collect all types of waste. For transportation of collected waste, airlines operating in the region have been coordinating with recycling initiatives to haul waste from Lukla to Kathmandu with no charge. Regular helicopter trips solely for this purpose could be costly, but it is known that the helicopters often transport cargo from Kathmandu to the Lukla airport area. On the way back to Kathmandu, without returning empty, the helicopters could carry some pre-processed waste as suggested in the SWM plan by Byers et al. (2019). Another method is road transportation which is being constructed up to Lukla. The road network will make the export of materials from Khumbu affordable, and hence, waste transport can be feasible. (Byers

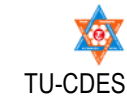


Nep J Environ Sci (2021), 9(2), 1-11

https://doi.org/10.3126/njes.v9i2.37381

et al., 2019). Apart from road transportation, a ropeway could ease the movement of waste from the upper hills to the lower ones within the region.

New steps could be initialized to mitigate solid waste problems from the growing number of visitors in the area. The solid waste segregated at the source could be transferred to the respective treatment facility as quickly as possible to prevent the spread of diseases and vectors. Preventing waste generation and composting biowaste and other organic waste can significantly reduce the quantity and volume of waste in dumpsites. If hazardous waste and bio-waste or organic wastes are poorly treated, they can harm the environment and human health, so it is important to segregate them from other wastes. Instead of collecting commingled waste in a single bin, different bins could be utilized to prevent the waste from mixing at the household level so that it can be treated according to their types afterward. In 2015, waste segregation at the source had been initiated, where two bins, one for recyclable waste and another for non-recyclable waste, were provided to lodge owners. The plan was not effective probably because back then, SPCC was unsure how to handle the collected waste, and they did not have a strong reason to impose a strict waste policy. After collaborating with recycling partners, SPCC is again planning for routine segregation of waste at its source by the lodge and homeowners (Y. Sherpa, personal communication, June 24, 2021). With this initiative, imposing strict rules and regulations on waste handling could start developing a more formal waste management system in the region. Also, the volume of waste could be reduced by folding cardboards and compressing plastic bottles and aluminum cans by hands or machinery like the waste press. Visitors should be encouraged to use reusable materials instead of disposable items such as paper towels and napkins (Lebersorger, 2011). Similar approaches have been considered in the "Carry Me Back" program, where processed waste is being carried back for further treatment and resource recovery.

A study showed that an effective way to generate less waste in mountainous regions is to provide bins at only strategic points through the trekking trail (Lebersorger, 2011). The goal is to create a well-managed integrated SWM system that requires a scientific approach and a social perspective. Promoting education on waste management to people living in mountain communities will also help to get a precise motive of integrated SWM and achieve clarity on the importance of sustainable development. For example, educational programs where people can learn to properly segregate and dispose of their waste could contribute to material recovery. Moreover, the interest of local people/communities to reduce waste can lead to the discovery of business opportunities such as waste to valuable goods.
As the waste generation is linked to the life cycle of products and materials, reusing and recycling are desirable options in waste management. However, recycling some products, for example, paper and glasses may be energy and water-intensive depending on the desired quality of recycled products and technology used (Björklund \& Finnveden, 2005). Moreover, due to limited resources and the lack of waste processing facilities in the SNPBZ, recyclable waste is primarily taken to Kathmandu for recycling. Any solid waste that's left behind is mostly incinerated/burned. Small constructive behavioral activities could change solid waste production, such as tourists bringing their refillable water bottles that can be reused throughout their stay. Further behavioral nudge ideas can be used in waste management for effective waste sorting at the source. For instance, using different colored bins with a name sticker on them is found more effective than using normal bins for waste sorting at the source (Samaranayake \& Thennakoon, 2021). It is indicated that specific types of architecture can enhance the waste collection process and promote new habit formation (McCoy et al., 2018). In addition, safe disposal practices, adoption of composting, feasible recycling methods, and re-using resources whenever possible could improve the waste situation.

Byers et al. (2019) reported more than dozens of buried pits in the region, some of which are located near the local water supplies. This practice can contaminate the soil and water nearby and bring harm to people's health. The active and buried dumping will keep affecting the environment unless the waste is excavated, segregated, pre-processed, and transported for recycling.

A draft management plan endorsed by the local government and SPCC has pointed out some priorities for SWM in SNPBZ (Byers et al., 2019). Such priorities include the establishment of environmental stations, MRFs, initiating door-to-door awareness campaigns, centralized/community composting systems, and finding cost-effective ways to transport waste. Additionally, the plan suggests the upcoming waste management schemes not based on displacement from one place to another, but the interest of participants on the innovative design of waste treatment technology as well as in waste policies/management capacities should be developed (Byers et al., 2019). In the long term, applying the polluter's pay principle could reduce the amount of waste generated. In 2014, the Government of Nepal had created a rule requiring all mountaineering expeditions to bring back $8 \mathrm{~kg}$ of trash per person or forfeit a deposit of $\$ 4,000$. However, this rule does not seem to be working effectively as planned (Maharjan \& Gustafsson, 2019). This may be possibly due to a lack of enforcement. Nonetheless, the burning of wastes should be immediately banned in the region as it is one of the worst ways to treat it.

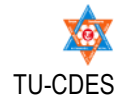


Nep J Environ Sci (2021), 9(2), 1-11

https://doi.org/10.3126/njes.v9i2.37381

Since the COVID-19 lockdown started in March 2020, there are only a few visitors in the region, which has had a negative impact on the economy, the local people, their communities, and their livelihoods. SPCC has been forced to reduce its operation to a minimum, as the ability to provide normal waste management services like the collection of solid waste has been severely impacted. The waste management plan developed (Fig. 4) seems to hold as long as the COVID-19 situation remains in place. After the situation normalizes, the plan is expected to resume the work of starting the building of infrastructure such as environmental stations, MRFs and restarting the Carry $\mathrm{Me}$ Back program. The intention is to replace the open dump with the environmental station for the waste enclosure and then transferring it to Kathmandu for upcycling or creating art. If the plan succeeds, the waste will be prevented from getting buried, but waste burning is still likely to continue. For this plan to be effectively implemented, it would be important that more waste handlers/ waste managers are engaged in the waste activity in the area. The long-term prospects for waste management may require support from policymakers and additional financial resources to increase the operational capacity considering the boom in tourism.

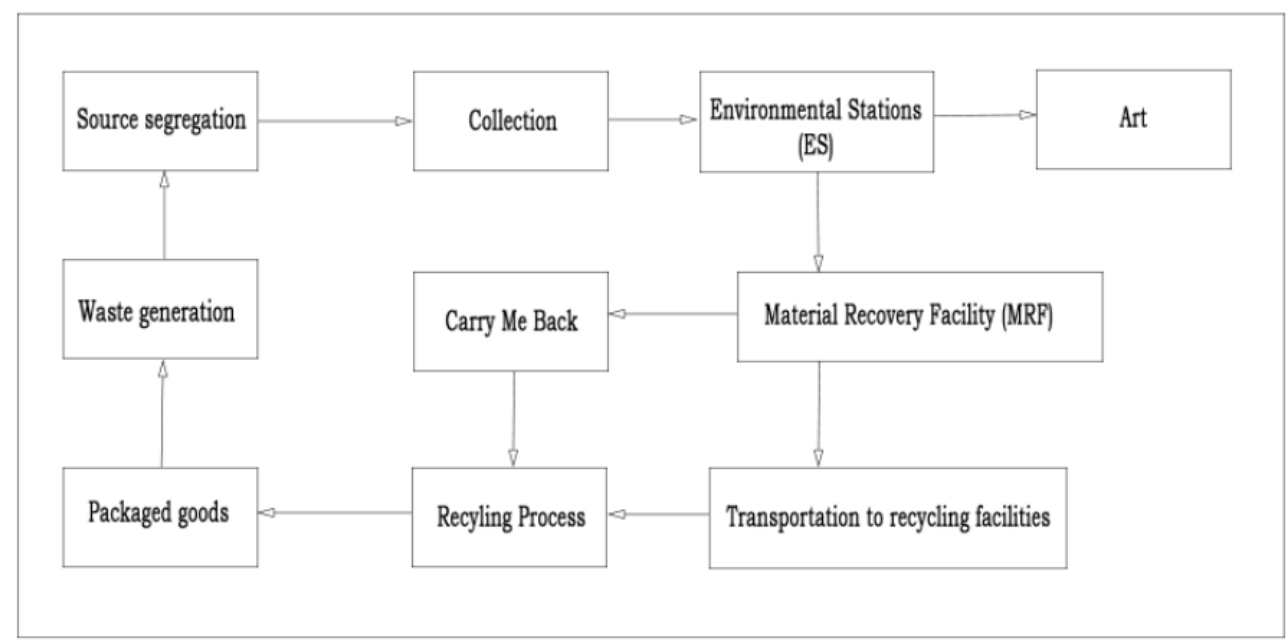

Figure 4 Proposed circular waste management system plan (Byers et al., 2019).

All things being considered, stakeholders from all walks of life should collectively seek a practical waste administration framework that is innovative and applicable in the Everest region (Himalayan News Service, 2019). To support their decision, visitors need to be educated to bring durable bottles made of metals or other reusable containers. Exhibition of environmentally conscious behavior should be demonstrated to everyone visiting the region. Even though holding an empty plastic bottle in hand feels troublesome for a while, the trekker should still do it until a garbage container is seen, as it promotes constructive environmental behavior. The release of empty bottles or waste from the hand to the ground may free the burden of it temporarily, but the person should be aware of its long-term destructive outcome. Generally, waste means 'unwanted', and thinking that we are responsible for the unwanted items and should be disposed of properly is a great way to start an environmentally conscious mindset.

Building awareness and promoting waste education at all levels is particularly needed in mountain areas. The mountain communities, local people, local businesses, stakeholders, travel/trekking/climbing companies, and small and large municipalities should collaborate to formulate a well-managed solid waste plan that can be easily implemented with available resources. All sectors, including residents who directly or indirectly are associated with the generation of waste in the mountain regions, should be responsible for improving and upgrading SWM facilities by contributing resources and helping in the management and enforcement of the waste plan (Alfthan et al., 2016). The small-scale solution, which is feasible for remote mountain settings such as segregating waste at source, alternative options for landfills like MRFs, and establishing environmental conscious behavior can be used to manage the waste successfully.

\section{Conclusions}

Solid waste generation in the Everest region is increasing with the number of tourists and tourism being the livelihood of the region, having a quota for visitors to the region may not be a proper solution to the waste issue. The earlier solid waste practices in the Everest region have contributed to contaminating the water bodies, degrading the soil quality, and 
has developed a risk for diseases. Due to the lack of proper waste management, this region is facing problems with sustainable waste handling. The practice of waste management activities by the SPCC and its partners has prevented the waste issue to some extent, but the solid waste problem is far from being resolved. The SPCC's further plan includes upgrading the waste management after the COVID-19 crisis by reaching out and encouraging all communities associated with the Everest region to participate and be a part of the solution willingly. While alternate solutions such as creating awareness among trekkers/backpackers/climbers/locals, other waste treatment options than landfilling, and waste segregation at source are being slowly implemented, it has not stopped the frequent burning/incineration practices. Perhaps, the Everest region could achieve sustainable SWM with the small-scale solutions feasible for remote mountain settings with a joint effort from policymakers, local authorities, local businesses, and organizations like SPCC. The Everest region must be prepared with practical SWM techniques, especially after the COVID-19 situation subsides since the tourist numbers are expected to increase. The application of behavioral change could enhance waste sorting practices. Furthermore, waste to art design must be adopted to develop environmental behavior. In the long haul, creating value from waste will promote art and potentially be an income generation source to the local community. Also, a circular system including source segregation, collection, MRF, and recycling should be considered major processes for attaining sustainable SWM in the mountain region.

Acknowledgements: We acknowledge the valuable suggestions provided by anonymous reviewers. We thank our key informants, Tommy Gustafsson, Nabin Bikash Maharjan, and Yangji Doma Sherpa, for their valuable time and information on the solid waste situation in the Everest region.

Author Contributions: SB: Literature review, data analysis and interpretation, writing original draft, and revision; AG: Conception, supervision, formal analysis, writing, reviewing, and editing; MBD: Conception, supervision, writing, reviewing, and editing.

Conflict of Interest: The authors declare no conflict of interest.

Data Availability Statement: The data that support the findings of this study are available from the corresponding author, upon reasonable request.

\section{References}

ADB. (2013). Solid waste management in Nepal: Current status and policy recommendations. Asian Development Bank. Mandaluyong City, Philippines. Retrieved October 12, 2020 from https://www.adb.org/sites/default/files/ publication/30366/solid-waste-management-nepal.pdf.
Afifah, U., \& Priadi, C.R. (2017). Biogas potential from anaerobic co-digestion of faecal sludge with food waste and garden waste. AIP Conference Proceedings 1826, 020032. https://doi.org/10.1063/1.4979248.

Alfthan, B., Semernya, L., Ramola, A., Adler, C., Peñaranda, L.F., Andresen, M., Rucevska, I., Jurek, M., Schoolmeester, T., Baker, E., Hauer, W., \& Memon, M. (2016). Waste Management Outlook for Mountain Regions - Sources and Solutions. UNEP, GRID-Arendal and ISWA. Nairobi, Arendal and Vienna.

Björklund, A., \& Finnveden, G. (2005). Recycling revisitedlife cycle comparisons of global warming impact and total energy use of waste management strategies. Resources, Conservation and Recycling, 44(4), 309-317. https:/ / doi.org/ 10.1016/j.resconrec.2004.12.002.

Byers, A.C., Gustafsson, T., Shrestha, M., \& Chhetri, N. (2020). A Sustainable Solid Waste Management Plan for Sagarmatha (Mt Everest) National Park and Buffer Zone, Nepal. Mountain Research and Development, 40(3), A1-A9. https://doi.org/10.1659/mrd-journal-d-20-00018.1.

Byers, A.C., Gustafsson, T., Shrestha, M., \& Chhetri, N. (2019). Sustainable Solid Waste Management in the Sagarmatha (Mt. Everest) National Park, Khumbu, Nepal. A Management Plan Report. Retrieved June 22, 2020 from https://www.sagarmathanext.com/wp-content/uploads/ 2021/04/Khumbu-Waste-Management-Plan-Nepal.pdf.

Cordrey, K. (2009). Biodegraable peepoo bags safely compost human waste. Retrieved April 2, 2020 from https://www.trendhunt er.com/trends/basic-sanitation-biodegradable-peepoobags-safely-compost-human-waste.

Wills, E. (2019). Human waste left by the record number of Everest climbers 'threatens local drinking water'. Retrieved June 29, 2021 from https://www.standard.co.uk/news/world/humanwaste-left-by-record-number-of-everest-climbers-threatens -local-drinking-water-a4174356.htmlon.

EBP. (2019). Traditional biogas system. Everest Biogas Project. Retrieved April 2, 2021 from http://mteverestbiogasproje ct.org/our-solution/.

Fox News. (2019). Mount Everest has become an 'open toilet', staggering amount of human waste found on its slopes. Retrieved April 2, 2020 from https://www.foxnews.com/world/mo unt-everest-has-human-waste-problem-official-says.

Ghimire, N.P., Shrestha, B.B, Caravello, G.U., \& Jha, P.K. (2010). Sources of water pollution in Sagarmatha National Park and Buffer Zone, Nepal. In Jha, P.K. (Ed.), Contemporary Research in Sagarmatha (Mt. Everest) Region, Nepal: An Anthology. Nepal Academy of Science and Technology, Kathmandu.

Himalayan News Service. (2019). 3,000 kg of garbage collected from $M t$ Everest region. The Himalayan Times. Retrieved January 19, 2020 from https://thehimalayantimes.com/business /3000-kg-of-garbage-collected-from-mt-everest-region/.

ICIMOD. (2011). Regional Database System. Retrieved January 20, 2020 from https://rds.icimod.org/Home/Data?any= sagarmatha\&Category $=$ datasets.

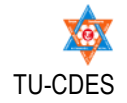


Nep J Environ Sci (2021), 9(2), 1-11

https://doi.org/10.3126/njes.v9i2.37381

Khanal, S.N. (2009). Solid waste management research in SNPBZ and its outcomes. Kathmandu University.

Lebersorger, S. (2011). Solid Waste Management in the mountains refuges - results and implications from a case study. IEVEBS, Sustainable Sanitation Practice, p. 13-19. Retrieved June 13, 2020 from http://www.ecosan.at/ssp/ issue-08-solutions-for-mountain-regions/SSP-08_Jul2011 13-19.

Maharjan, N.B, \& Gustafsson, T. (2019). Solid Waste Management in the Khumbu Region: Current Status, Analysis of Waste Generation and Possible Environment- Friendly Management Solutions. Report, Kathmandu, Nepal: Sagarmatha Next, Himalayn Museum and Sustainabe Park.

Manfredi, E.C., Flury, B., Viviano, G., Thakuri, S., Khanal, S.N., Jha, P.K., Maskey, R.K., Kayastha, R.B., Kafle, K.R., Bhochhibhoya, S., \& Ghimire, N.P. (2010). Solid waste and water quality management models for Sagarmatha National Park and Buffer Zone, Nepal. Mountain Research and Development, 30(2), 127-142.

McCoy, K., Oliver, J.J., Borden, D.S., \& Cohn, S.I. (2018). Nudging waste diversion at Western State Colorado University: application of behavioral insights. International Journal of Sustainability in Higher Education, 19(3), 608-621. https://doi.org/10.1108/ijshe-05-2017-0063 .

Nepal, S. (2005). Tourism and Remote Mountain Settlements: Spatial and Temporal Development of Tourist Infrastructure in the Mt Everest Region, Nepal. Tourism Geographies, 7(2), 205-227. https://doi.org/10.1080/14616 680500072471

Nepal, S.K., (2016). Tourism and change in Nepal's Mt Everest Region. Mountain Tourism: Experiences, Communities, Environments and Sustainable Futures, 270-279. https://doi.org/10.1079/9781780644608.0270.

Nepal Tourism Statistics. (2018). Government of Nepal. Ministry of Culture, Tourism \& Civil Aviation. Retrieved April 3, 2020 from https://tourism.gov.np/files/statistics /19.pdf.

Nicholson, K.N., Neumann, K., Dowling, C., Gruver, J., Sherman, H., \& Sharma, S. (2018). An assessment of drinking water sources in Sagarmatha National Park (Mt Everest region), Nepal. Mountain Research and Development, 38(4), 353. doi: 10.1659/mrd-journal-d-1700024.1.

Nicholson, K.N., Neumann, K., Sharma, S., \& Dowling, C., (2017). E. coli and coliform bacteria as indicators for drinking water quality and handling of drinking water in the Sagarmatha National Park, Nepal. Journal of Environmental Management and Sustainable Development, 6(2), 412-424.

Pant, S. (2021). Carry Me Back: How campaigners are making Everest cleaner again. Retrieved June 27, 2021 from https://english.onlinekhabar.com/carry-me-back-howcampaigners-are-making-everest-cleaner-again.html.

Pillai, S., Peter, E.A., Sunil, B.M., \& Shrihari, S. (2014). Soil pollution near a municipal solid waste disposal site in India. Proceedings of International Conference on Biological, Civil and Environmental Engineering (BCEE-2014) March 17-18, 2014. Dubai, UAE. https://dx.doi.org/10.15242/IICBE.C 0314080 .

Posch, E., Bell, R., Weidinger, J.T., \& Glade, T. (2015). Geomorphic Processes, Rock Quality and Solid Waste Management-Examples from the Mt. Everest Region of Nepal. Journal of Water Resource and Protection, 07(16), 19211308.

Rajagopal, R., Lim, J.W., Mao, Y., Chen, C.L., \& Wang, J.Y. (2013). Anaerobic co-digestion of source segregated brown water (feces-without-urine) and food waste: For Singapore context. Science of the Total Environment, 443, 877-886.

Samaranayake, D.I.J., \& Thennakoon, R.S. (2021). Could Behavioural Nudges Improve the Accuracy of Waste Sorting? An Experiment Survey. Environment and Pollution, 10(1), 1. https://doi.org/10.5539/ep.v10n1p1

SPCC. (2018). Annual Report 2018. Sagarmatha Pollution Control Committee (SPCC). Retrieved April 4, 2020) from https://spcc.org.np/uploads/2019/04/annual-reportspcc-2018-final-lq-copy.pdf.

SPCC. (2020). Sagarmatha Pollution Control Committee (SPCC). Retrieved January 19, 2020 from https://www. spcc.org.np/.

UNESCO. (2007). World Heritage Convention. UNESCO (United Nations Educational, Scientific and Cultural Organization). Retrieved February 19, 2020 from https://whc.unesco.org/en/list/120/.

USEPA. (2000). Nutrient Criteria Technical Guidance Manual: Rivers and Streams. The United States Environmental Protection Agency (USEPA): Washington, DC.

World Bank. (2021). Nepal: Sustainable solid waste management in mountain areas. Washington DC: The World Bank.

Zuser, A., Fellner, J., \& Lederer, J. (2011). Final Repot: Managing the solid waste of Sagarmatha National Park and its Buffer Zone. University of Technology, Vienna. 